Volume 2 Issue 2, September 2018: pp. 484-497. Copyright (c) 2018 HOLREV. Faculty of Law, Halu Oleo University, Kendari, Southeast Sulawesi, Indonesia. ISSN: 2548-1762 | e-ISSN: 2548-1754. Open Access at: http://ojs.uho.ac.id/index.php/holrev/

Halu Oleo Law Review is licensed under a Creative Commons Attribution 4.0 International License, which permits unrestricted use, distribution, and reproduction in any medium, provided the original work is properly cited.

\title{
Perspektif Hukum Perjanjian Kerja Perseroan Terbatas State Development and Investment Corporation (SDIC) Papua Indonesia Cement Manokwari
}

\author{
Legal Perspective on Agreement of Limited Company (PT.) of State \\ Development and Investment Corporation (SDIC) Papua Indonesia Cement \\ Manokwari
}

\author{
Anace Nauw \\ Fakultas Hukum Universitas Hasanuddin \\ E-mail: imanuelmdumais@gmail.com \\ Abrar Saleng \\ Fakultas Hukum Universitas Hasanuddin \\ E-mail: abrarsaleng@unhas.ac.id \\ Musakkir \\ Fakultas Hukum Universitas Hasanuddin
}

\begin{abstract}
The issue of employment is one of the important issues that need attention in both national and international level. This study aims to determine the implementation of work agreements between workers/employees with PT. SDIC Papua Indonesia Cement Manokwari. This research is an empirical legal research by reviewing and analyzing some relevant laws relevant to practical research issues. The results showed that the employment agreement between employees with PT. SDIC Manokwari Papua Indonesia Cement is basically an agreement between employers and the unions, however unequal position economically, resulting in the deal goes one way in which companies are dominant in determining the content of the contract, so that the principle of freedom of contract are lacking. Implementation of agreements between workers / employees with PT. SDIC Papua Indonesia Cement Manokwari in obtaining basic rights wages are poorly implemented.
\end{abstract}

Keyword: Employment; Employment Relationships; Employment Agreement

Abstrak: Isu ketenagakerjaan merupakan salah satu isu penting yang perlu mendapat perhatian baik di tingkat nasional maupun di dunia internasional. Penelitian ini bertujuan untuk mengetahui pelaksanaan perjanjian kerja antara pekerja/karyawan dengan PT. SDIC Papua Indonesia Cement Manokwari. Penelitian ini merupakan penelitian hukum empiris dengan mengkaji dan menganalisis beberapa undang-undang yang berkaitan dan relevan dengan isu penelitian pada 
tataran praktis. Hasil penelitian menunjukkan bahwa perjanjian kerja antara karyawan dengan PT. SDIC Papua Indonesia Cement Manokwari pada dasarnya merupakan kesepakatan pihak perusahaan dengan pihak serikat pekerja, namun demikian kedudukan yang tidak berimbang secara ekonomis, mengakibatkan kesepakatan berjalan satu arah dimana perusahaan lebih dominan dalam menentukan isi kontrak, sehingga asas kebebasan berkontrak kurang terpenuhi. Pelaksanaan perjanjian antara pekerja/karyawan dengan PT. SDIC Papua Indonesia Cement Manokwari dalam memperoleh hak-hak dasar Pengupahan kurang terimplementasi dengan baik.

Kata kunci: Ketenagakerjaan; Hubungan Kerja; Perjanjian Kerja

\section{PENDAHULUAN}

Secara universal, pengakuan terhadap hak-hak pekerja telah ditegaskan pada Pasal 23 ayat (3) Deklarasi Universal HAM PBB, bahwa setiap orang yang melakukan pekerjaan berhak atas pengupahan yang adil dan baik, yang menjamin kehidupannya bersama dengan keluarga, sepadan dengan martabat manusia, dan jika ditambah dengan bantuan-bantuan sosial lainnya. Dengan demikian, ketenagakerjaan memiliki kaitan yang erat dengan kemampuan penduduk memenuhi kebutuhan hidupnya yang secara tidak langsung berhubungan erat dengan kesejahteraan masyarakat. ${ }^{1}$ Lebih dari itu, pada isu ketenagakerjaan masih sarat dengan praktik ketidakadilan dimana hak-hak kaum buruh masih cenderung dilanggar.

Pada prinsipnya, ada 3 unsur penting yang saling mempengaruhi yang menjadi indikator penentu dalam menciptakan hubungan sehat dalam dunia ketenagakerjaan. Apabila salah satu fungsi dan peran dari ketiga unsur ini tidak berjalan, maka kondisi ketenagakerjaan tidak akan berjalan secara sehat. Ketiga unsur tersebut terdiri dari Pekerja, Pengusaha dan Pemerintah yang dalam istilah ketenagakerjaan dikenal dengan istilah Tripartit.

Dari ketiga unsur tripartit tersebut memiliki keinginan yang berbeda-beda dan masih banyak yang belum bisa mewujudkan hubungan yang saling memenuhi keinginannya masing-masing. Untuk terciptanya hubungan yang saling menguntungkan keinginan masing-masing unsur tripartit tersebut, pemerintah telah mengaturnya dengan

1 Rizka Amelia Aziz, "Penerapan Perjanjian Kerja Waktu Tertentu (PKWT) Terhadap Pekerja Outsourcing Pasca Putusan MK No. 27/PUU-IX/2011" Jurnal Hukum Lex Jurnalica Vol.13 No.3, 2016. 
regulasi yaitu Pasal 102 UU No. 13 Tahun 2003 (UU Ketenagakerjaan) yang mengatur Fungsi Dan Peran Pemerintah, Pekerja dan Perusahaan dalam ketenagakerjaan.

Fungsi pekerja atau buruh sebagaimana tersebut dalam Pasal 102 ayat (2) UndangUndang Nomor 13 Tahun 2003 selanjutnya akan terlaksana dengan baik apabila fungsi dan peran pemerintah sebagaimana ayat sebelumnya berjalan dengan baik dan benar, terutama dalam memastikan terpenuhinya hak-hak pekerja yang merupakan kewajiban pengusaha untuk memenuhinya. Yang paling dirugikan ketika fungsi masing-masing tersebut tidak berjalan sebagaimana mestinya adalah pekerja, karena akibat lemahnya fungsi pemerintah, hak-hak pekerja yang merupakan kewajiban pengusaha masih banyak yang tidak terpenuhi, padahal setiap hak pekerja yang sudah diatur dalam UU Ketenagakerjaan dilanggar ada sanksi baik administratif maupun pidana.

Salah satu permasalahan ketenagakerjaan yang masih terjadi di Indonesia adalah tidak proporsionalnya upah buruh berdasarkan tingkat inflasi yang terjadi di suatu daerah. Hal ini dapat di lihat pada daerah yang memiliki inflasi cukup tinggi seperti di daerah Papua. Data Badan Pusat Statistik (BPS) dalam Survei Angkatan Kerja Nasional (Sakernas) Agustus 2016, menyebutkan bahwa DKI Jakarta merupakan provinsi dengan rata-rata gaji pegawai tertinggi di Indonesia. Gaji yang didapatkan pekerja formal di ibu kota rata-rata mencapai Rp 3,98 juta. Selanjutnya Kalimantan Timur dan Banten dengan masing-masing Rp 3,7 juta dan Rp 3,5 juta. Provinsi paling timur yakni Papua, menempati posisi ke-4 dengan rata-rata gaji pekerja di sana senilai Rp 3,4 juta mengalahkan Jawa Barat dengan rata-rata upah $\operatorname{Rp} 2,8$ juta. $^{2}$

Permasalahan lainnya yang juga masih belum terselesaikan hingga saat ini adalah adanya perselisihan antara buruh dan pihak perusahaan terkait dengan hak-hak buruh yang tidak terealisasi sebagai mana perjanjian kerja yang dibuat. Hal inilah yang terjadi pada salah satu perusahaan di Manokwari, Perseroan Terbatas State Development \& Investment Corporation Papua Indonesia Cement Manokwari. Pada perusahaan tersebut, telah terjadi mogok kerja yang dilakukan pihak buruh, karena adanya ketidakjelasan upah yang dibayarkan pihak perusahaan, karena tidak sesuai dengan kontrak kerja dan aturan

2 Badan Pusat Statistik, "Rata-rata Gaji di Papua Kalahkan Jawa Barat", Katadata, http://databoks.katadata.co.id/datapublish/2017/01/27/10-provinsi-dengan-rata-rata-gaji-pekerjaterbesar, diakses pada tanggal 14 Oktober 2017, Pukul 09.00. 
ketenagakerjaan. ${ }^{3}$ Bahkan dalam upaya penyelesaiannya terjadi aksi saling tuding antara pemerintah provinsi dan pemerintah Kab/Kota dalam menangani urusan ini.

Hal ini menunjukkan bahwa peran pemerintah dalam memperjuangkan hak-hak buruh di beberapa daerah masih kurang optimal, sehingga kesejahteraan buruh tidak terwujud. Hal inilah yang dialami buruh masyarakat asli Papua yang bekerja pada PT. SDIC Papua Indonesia Cement Manokwari. Rendahnya upah buruh dan terbatasnya hak-hak pekerja seperti Jaminan Kecelakaan Kerja, Jaminan kematian, Jaminan Hari Tua dan Jaminan Pemeliharaan Kesehatan merupakan salah satu bentuk pengabaian terhadap hak dasar pekerja. Hal inilah yang melatarbelakangi penulis mengangkat permasalahan ini dalam sebuah tesis dengan Judul Analisis Hukum Perjanjian Kerja Pada Perseroan Terbatas State Development and Investment Corporation Papua Indonesia Cement Manokwari (Studi Kasus Kontrak Kerja Perseroan Terbatas State Development \& Investment Corporation Papua Indonesia Cement Manokwari).

Hak dan kewajiban merupakan sesuatu yang tidak dapat dipisahkan, akan tetapi terjadi pertentangan karena hak dan kewajiban tidak seimbang. ${ }^{4}$ Setiap warga negara memiliki hak dan kewajiban untuk mendapatkan penghidupan yang layak, tetapi pada kenyataannya seperti halnya kasus di atas, banyak warga negara yang belum merasakan kesejahteraan dalam menjalani kehidupannya, karena haknya belum terjamin sepenuhnya. Jika keadaannya seperti ini, maka tidak ada keseimbangan antara hak dan kewajiban. Jika keseimbangan itu tidak ada akan terjadi kesenjangan sosial yang berkepanjangan.

Bentuk perlindungan tenaga kerja di Indonesia yang wajib dilaksanakan oleh setiap pengusaha atau perusahaan yang mempekerjakan orang untuk bekerja pada perusahaan tersebut harus sangat diperhatikan, yaitu mengenai pemeliharaan dan peningkatan kesejahteraan di maksud diselenggarakan dalam bentuk jaminan sosial tenaga kerja yang bersifat umum untuk dilaksanakan atau bersifat dasar, dengan berasaskan usaha bersama, kekeluargaan dan kegotongroyongan sebagai mana yang tercantum dalam jiwa dan semangat Pancasila dan Undang-Undang Dasar 1945.

3 Pasific Pos, "250 Pekerja Lebih PT SDIC Cement Indonesia Mogok", Pasific Pos, https://www.pasificpos.com/item/16495-250-pekerja-lebih-pt-sdic-cement-indonesia-mogok. Diakses taggal 13 Januari 2017. Pukul 14.00 WIT.

4 Subir K. Roy. "Vulnerability of Elderly Women: Victim of Gender Discrimination". Hasanuddin Law Review, 3(1), 1-13, 2017, doi: http://dx.doi.org/10.20956/halrev.v3i1.560 
Perlindungan terhadap tenaga kerja dimaksudkan untuk menjamin hak-hak dasar pekerja dan menjamin kesamaan serta perlakuan tanpa diskriminasi atas dasar apa pun untuk mewujudkan kesejahteraan pekerja dan keluarganya dengan tetap memperhatikan perkembangan kemajuan dunia usaha dan kepentingan pengusaha. Peraturan perundangundangan yang terkait dengan perlindungan bagi pekerja Undang-Undang No. 13 Tahun 2003 Tentang Ketenagakerjaan dan Peraturan Pelaksana dari perundang-undangan di bidang Ketenagakerjaan.

Permasalahan ketenagakerjaan di Indonesia terkait mengenai hubungan kerja tidak seimbang antara pengusaha dengan buruh dalam pembuatan perjanjian kerja sebagaimana pada State Development And Investment Corporation Papua Indonesia Cement Manokwari, Bukan hanya tidak seimbang dalam membuat perjanjian, akan tetapi iklim persaingan usaha yang makin ketat yang menyebabkan perusahaan melakukan efisiensi biaya produksi (cost of production). Namun hal ini justru berdampak pada implementasi hak pekerja yang tidak terpenuhi sehingga perjanjian kerja yang di buat, cenderung hanya menguntungkan pihak perusahaan saja.

\section{METODE PENELITIAN}

Penelitian ini merupakan penelitian hukum empiris dengan mengkaji dan menganalisis beberapa undang-undang yang berkaitan dan relevan dengan isu penelitian pada tataran praktis. Lokasi penelitian dilakukan di Kantor Dinas Tenaga Kerja dan Transmigrasi Manokwari serta Perseroan Terbatas State Development dan Investment Corporation Papua Indonesia Cement Manokwari. Pemilihan lokasi Penelitian ini didasarkan pada pertimbangan bahwa lokasi tersebut di atas merupakan lembaga yang berwenang dalam melakukan pengawasan terhadap terlaksananya Undang-Undang Ketenagakerjaan, sedangkan PT SDIC Papua Indonesia Cement Manokwari merupakan perusahaan yang banyak mempekerjakan masyarakat asli Papua.

\section{ANALISIS DAN PEMBAHASAN}

Analisis Perjanjian Kerja antara Karyawan dengan PT. SDIC Papua Indonesia

\section{Cement Manokwari}

Di Indonesia, konsep hak asasi manusia secara tegas diakui keberadaannya di dalam UUD NRI 1945 dilaksanakan oleh negara di dalam masyarakat. Hak asasi pekerja adalah hak untuk memperoleh pekerjaan yang layak bagi kemanusiaan yang telah diakui 
keberadaannya dalam UUD NRI 1945 yang merupakan hak konstitusional. Permasalahan ketenagakerjaan di Indonesia terkait mengenai hubungan kerja tidak seimbang antara pengusaha dengan pekerja dilatarbelakangi karena adanya ketidakseimbangan posisi dalam pembuatan perjanjian kerja. Hubungan kerja yang dilakukan oleh pekerja dan perusahaan pada umumnya bersifat hubungan hierarkis. Kedudukan pekerja di dalam hubungan kerja, ditinjau dari segi sosial ekonomis adalah lebih rendah dari perusahaan.

Perjanjian kerja mempunyai beberapa pengertian. Pasal 1601 a dalam Kitab Undang-undang Hukum Perdata (KUHPerdata) menegaskan:

"Perjanjian perburuhan adalah suatu perjanjian dimana pihak ke-1 (satu)/buruh atau pekerja mengikatkan dirinya untuk dibawah perintah pihak yang lain, si majikan untuk suatu waktu tertentu melakukan pekerjaan dengan menerima upah". Selanjutnya, pada Undang-Undang Nomor. 13 Tahun 2003 Tentang Ketenagakerjaan, Pasal 1 ayat (14) menyebutkan:

"Perjanjian kerja adalah suatu perjanjian antara pekerja/buruh dan pengusaha atau pemberi kerja yang memuat syarat-syarat kerja hak dan kewajiban kedua belah pihak".

Perihal tentang pengertian perjanjian kerja, Imam Soepomo berpendapat bahwa perjanjian kerja adalah suatu perjanjian dimana pihak kesatu (buruh), mengikatkan diri untuk bekerja dengan menerima upah dari Pihak Kedua yakni majikan, dan majikan mengikatkan diri untuk memperkerjakan buruh dengan membayar upah. ${ }^{5}$

Menyimak pengertian perjanjian kerja menurut, bahwa ciri khas perjanjian kerja adalah" adanya di bawah perintah pihak lain", sehingga tampak hubungan antara pekerja dan pengusaha adalah hubungan bawahan dan atasan. Berdasarkan pengertian perjanjian kerja di atas, dapat ditarik beberapa unsur dari perjanjian kerja, yakni:

a. Adanya Unsur Pekerjaan

Dalam suatu perjanjian kerja harus ada pekerjaan yang diperjanjikan (objek perjanjian), pekerjaan tersebut haruslah dilakukan sendiri oleh pekerja, hanya dengan seizin majikan dapat menyuruh orang lain. Hal ini dijelaskan dalam Kitab Undang-undang Hukum Perdata (KUHPerdata) Pasal 1603a yang berbunyi : "Buruh wajib melakukan sendiri pekerjaannya; hanya dengan seizin majikan ia dapat menyuruh orang ketiga menggantikannya". Sifat pekerjaan

5 Agusmidah, Dinamika Hukum Ketenagakerjaan Indonesia, Medan: USU Press, 2010, hlm. 40. 
yang dilakukan oleh pekerja itu sangat pribadi karena bersangkutan keterampilan/keahliannya, maka menurut hukum jika pekerja meninggal dunia maka perjanjian kerja tersebut putus demi hukum.

b. Adanya Unsur Perintah

Manifestasi dari pekerjaan yang diberikan kepada pekerja oleh pengusaha adalah pekerja yang bersangkutan harus tunduk pada perintah pengusaha untuk melakukan pekerjaan sesuai dengan yang diperjanjikan. Di sinilah perbedaan hubungan kerja dengan hubungan lainnya. Perjanjian Kerja sebagaimana didefinisikan oleh ketentuan pasal 1313 Kitab Undang-undang Hukum Perdata (KUHPerdata) yang berbunyi: "Suatu perjanjian adalah suatu perbuatan dengan mana satu orang atau lebih mengikatkan dirinya terhadap satu orang lain atau lebih". Perjanjian dengan demikian mengikat para pihak secara hukum, untuk mendapatkan hak atau melaksanakan kewajiban yang ditentukan dalam perjanjian tersebut.

c. Adanya Unsur Upah

Upah memegang peranan penting dalam hubungan kerja, bahkan dapat dikatakan bahwa tujuan utama orang bekerja pada pengusaha adalah untuk memperoleh upah. Sehingga jika tidak unsur upah, maka suatu hubungan tersebut bukan merupakan hubungan kerja. Sebagai bagian dari perjanjian pada umumnya, perjanjian kerja harus memenuhi syarat sahnya perjanjian sebagaimana diatur dalam Pasal 1320 Kitab Undang-undang Hukum Perdata (KUHPerdata) dan juga pada Pasal 1 ayat 14 Pasal 52 ayat 1 Undang Undang Nomor. 13 Tahun 2003 Tentang Ketenagakerjaan, definisi perjanjian kerja adalah perjanjian antara pekerja/buruh dengan pengusaha atau pemberi kerja yang memuat syarat-syarat kerja, hak dan kewajiban para pihak.

Kesepakatan kedua belah pihak yang lazim disebut kesepakatan bagi yang mengikatkan dirinya, bahwa pihak-pihak yang mengadakan perjanjian kerja harus setuju/sepakat, seia-sekata mengenai hal-hal yang diperjanjikan. Kemampuan atau kecakapan kedua belah pihak yang membuat perjanjian harus haruslah cakap membuat perjanjian (tidak terganggu kejiwaan/waras) ataupun cukup umur minimal 18 Tahun (Pasal 1 ayat 26 Undang-Undang Nomor. 13 Tahun 2003 Tentang Ketenagakerjaan).

Perjanjian kerja, seyogyanya di buat dengan kesepakatan kedua belah pihak dengan mengedepankan asas keseimbangan para pihak. Kedudukan yang tidak seimbang akan 
berakibat pada ketimpangan hak dan kewajiban salah satu pihak. PT. SDIC Papua Indonesia Cement Manokwari dalam mengadakan perjanjian kerja dengan pekerja, menggunakan standar kontrak yang belum pernah di diskusikan bersama dengan sekrikat pekerja. Berdasarkan hasil wawancara pada bagian Human Resources Departement PT. SDIC Papua Indonesia Cement Manokwari pada tanggal 6 Maret 2018, mengemukakan bahwa bentuk standar kontrak yang digunakan pada dasarnya sifatnya seragam karena merupakan kebijakan kantor pusat yang berkedudukan di China. Cabang yang ada di berbagai negara tidak memiliki kewenangan untuk melakukan perubahan terhadap isi standar kontrak tersebut, cabang hanyalah pelaksana kebijakan. Penggunaan standar kontrak tidak dapat dihindarkan mengingat kebutuhan perekonomian mengharuskan pihak perusahaan bertindak cepat dan efisien. Sehingga salah satu upaya untuk memperlancar jalannya kegiatan rekrutmen pekerja adalah dengan menggunakan standar kontrak, agar lebih efisiensi pola penerimaan pekerja. Selain itu, isi kontrak ini juga telah dibicarakan dengan organisasi serikat buruh dan pada dasarnya semua telah setuju.

Penulis berpandangan bahwa, meskipun pada dasarnya penggunaan standar kontrak memang ditujukan untuk efisiensi proses pelaksanaan penerimaan pekerja yang jumlahnya banyak, namun demikian ikut merumuskan kontrak merupakan bagian dari salah satu kesepakatan dalam hukum perdata. Hal ini tentu menjadi pertanyaan besar, benturan antara tuntutan efisiensi dan keseragaman dengan upaya menciptakan keadilan bagi para pekerja adalah hal yang tidak dapat terhindarkan. Namun demikian, bukan berarti bahwa tuntutan efisiensi tersebut harus mengesampingkan hak-hak salah satu pihak dalam pembuatan perjanjian kerja.

Berkaitan dengan standar kontrak ini, maka penulis berpandangan bahwa pembuatan perjanjian yang dilakukan oleh satu pihak saja, tanpa ada keterlibatan secara aktif oleh pihak lainnya sangat bertentangan dengan asas kebebasan berkontrak sebagaimana ditentukan dalam Pasal 1338 ayat (1) KUHPerdata. Asas kebebasan berkontrak (contracts vrijheid) mengandung makna bahwa masyarakat memiliki kebebasan untuk membuat perjanjian sesuai dengan kehendak dan kepentingan mereka. ${ }^{6}$

Perkembangan yang terjadi dalam praktik, terkait dengan kontrak kerja, terdapat indikasi terjadinya penyalahgunaan keadaan yang menjadi salah satu faktor pembatas

6 Sutan Remy Sjahdeini, Kebebasan Berkontrak dan Perlindungan Yang Seimbang Bagi Para Pihak Dalam Perjanjian Kredit Bank di Indonesia. Jakarta: Institut Bankir Indonesia, 1993, hlm. 47. 
dalam penerapan asas kebebasan berkontrak. ${ }^{7}$ Berbeda dengan aturan hukum kontrak yang berlaku di Indonesia, yang belum mengatur penyalahgunaan keadaan, tetapi masih memakai rubrikasi paksaan, tipuan, dan khilaf sebagai dasar untuk menyatakan cacatnya kesepakatan, maka KUH. Perdata Belanda baru yang terdapat dalam NBW (Nieuw Burgerlijk Wetbook) telah menetapkan penyalahgunaan keadaan menjadi salah satu alasan untuk membatalkan kontrak. ${ }^{8}$

Dari berbagai pandangan yang dikemukakan, ternyata asas kebebasan berkontrak merupakan domain terpenting dalam hukum kontrak. Asas kebebasan berkontrak merupakan asas yang bersifat universal, karena diakui dalam sistem civil law dan common law, yang dalam perkembangannya cenderung dipenuhi dengan pembatasan-pembatasan. Diasumsikan, bahwa kebebasan tanpa batas akan cenderung kepada terjadinya penyalahgunaan dan perbuatan merugikan bagi satu pihak yang berada dalam posisi tawar yang lemah. Kebebasan berkontrak merupakan "ruh" dan "nafas" sebuah kontrak, yang secara implisit memberi panduan bahwa dalam berkontrak para pihak diasumsikan mempunyai kedudukan yang seimbang. Dengan demikian, diharapkan muncul kontrak yang adil dan seimbang bagi para pihak. ${ }^{9}$

Dalam perkembangannya ternyata kebebasan berkontrak dapat mendatangkan ketidakadilan, karena asas ini hanya mencapai tujuannya yaitu mendatangkan kesejahteraan seoptimal mungkin bila para pihak memiliki bargaining position yang seimbang. ${ }^{10}$ Karena itu, asas kebebasan berkontrak telah mengalami penurunan secara fungsional, karena kuatnya intervensi Kedudukan Perusahaan dalam membatasi pekerja dalam menciptakan dan mengatur hubungan kontraktual, sekalipun telah di rumuskan bersama melalui serikat pekerja/buruh. Oleh karenanya peran pemerintah dalam upaya mewakili pekerja dalam negeri harus lebih dioptimalkan khususnya dalam mewujudkan keadilan dalam hal pengupahan.

Dalam perspektif hukum perdata, perjanjian kerja haruslah memuat empat asas, yaitu asas kebebasan berkontrak, asas itikad baik, asas transparansi, dan asas proporsionalitas. ${ }^{11}$ Asas-asas hukum haruslah terpenuhi secara keseluruhan agar dapat

7 Zaeni Asyhadie, Hukum Kerja, Jakarta : RajaGrafindo Persada, 2007, hlm. 22.

8 Herlien Budiono, Kumpulan Tulisan Hukum Perdata di Bidang Kenotariatan, Bandung: Citra Aditya Bakti, 2007, hlm. 17.

9 Lalu Husni, Hukum Ketenagakerjaan Indonesia, Jakarta: Raja Grafindo Persada, 2000, hlm. 2.

10 Sutan Remy Sjahdeini. Op. Cit., hlm. 17.

11 Yohanes Sogar Simamora, Hukum Perjanjian, Prinsip Hukum Kontrak Pengadaan Barang Dan Jasa Oleh Pemerintah. Yogyakarta: LaksBang Pressindo, 2009, hlm. 37. 
mewujudkan keadilan bagi para pihak. Berikut ini adalah implementasi asas-asas perjanjian pada perjanjian kerja antara karyawan dengan PT. SDIC Papua Indonesia Cement Manokwari.

\section{Pelaksanaan Perjanjian Antara Pekerja/Karyawan Dalam Memperoleh Hak-hak Dasar Pengupahan}

Kebijakan Upah Minimum Regional (UMR) merupakan kebijakan yang wajib ditaati oleh setiap perusahaan di Indonesia. Besarnya upah minimum di setiap daerah berbeda-beda tergantung sumber daya manusia, potensi dan kemajuan ekonomi daerah serta daya saing suatu daerah dengan daerah lain. Kewajiban bagi setiap perusahaan untuk melaksanakan kebijakan upah minimum regional berdasarkan ketentuan Undang-Undang Ketenagakerjaan Pasal 90 ayat (1). Kewenangan Provinsi sebagai Daerah Otonom mencangkup kewenangan dalam bidang pemerintahan yang bersifat lintas kabupaten dan kota serta kewenangan dalam bidang pemerintahan tertentu lainnya.

Undang-Undang Nomor 21 Tahun 2001 Tentang Otonomi Khusus Bagi Provinsi Papua, tidak mengatur secara detail bagaimana peran Pemerintah daerah dalam melakukan pengawasan di bidang ketenagakerjaan. Undang-Undang Otsus tersebut hanya mengatur ketentuan sebagai berikut:

Pasal 61

(1) Pemerintah Provinsi berkewajiban melakukan pembinaan, pengawasan, dan pengendalian terhadap pertumbuhan penduduk di Provinsi Papua.

(2) Untuk mempercepat terwujudnya pemberdayaan, peningkatan kualitas dan partisipasi penduduk asli Papua dalam semua sektor pembangunan Pemerintah Provinsi memberlakukan kebijakan kependudukan.

(3) Penempatan penduduk di Provinsi Papua dalam rangka transmigrasi nasional yang diselenggarakan oleh Pemerintah dilakukan dengan persetujuan Gubernur.

(4) Penempatan penduduk sebagaimana dimaksud pada ayat (3) ditetapkan dengan Perdasi.

Pasal 62

(1) Setiap orang berhak atas pekerjaan dan penghasilan yang layak serta bebas memilih dan/atau pindah pekerjaan sesuai dengan bakat dan kemampuannya.

(2) Orang asli Papua berhak memperoleh kesempatan dan diutamakan untuk mendapatkan pekerjaan dalam semua bidang pekerjaan di wilayah Provinsi Papua berdasarkan pendidikan dan keahliannya.

(3) Dalam hal mendapatkan pekerjaan sebagaimana dimaksud pada ayat (2) di bidang peradilan, orang asli Papua berhak memperoleh keutamaan untuk diangkat menjadi Hakim atau Jaksa di Provinsi Papua. (4) Ketentuan sebagaimana dimaksud pada ayat (1) dan ayat (2) diatur lebih lanjut dengan Perdasi. 
Peran pemerintah daerah dalam bidang tenaga kerja secara tegas di atur dalam Undang-Undang Nomor 23 Tahun 2014 tentang pemerintah Daerah yang selanjutnya disebut UU Pemerintahan Daerah pada Pasal 9 ayat 3 dinyatakan Urusan pemerintahan konkuren sebagaimana dimaksud pada ayat (1) adalah Urusan Pemerintahan yang dibagi antara Pemerintah Pusat dan Daerah provinsi dan Daerah kabupaten/kota. Selanjutnya pada Pasal 12 UU Pemerintah Daerah ayat 2 dinyatakan bahwa salah satu urusan konkuren pemerintah daerah adalah berkenaan dengan ketenagakerjaan.

Pemerintah mempunyai fungsi utama membuat pengaturan agar hubungan antara buruh dengan pengusaha berjalan serasi dan seimbang yang dilandasi oleh pengaturan hak dan kewajiban secara adil, serta berfungsi sebagai penegak hukum. Di samping itu pemerintah juga berperan sebagai penengah dalam menyelesaikan konflik atau perselisihan yang terjadi secara adil. Peran Disnakertrans dalam pelaksanaan dan pengawasan kebijakan upah minimum juga berdasarkan adanya surat wajib lapor perusahaan, dimana di dalamnya berisi kodifikasi perusahaan, keadaan perusahaan, Keadaan ketenagakerjaan, dan pengesahan. Setiap laporan yang dikumpulkan oleh semua perusahaan yang berada di wilayah Manokwari yang nantinya akan menjadi dasar dari bidang pengawasan untuk mengambil tindakan guna melindungi tenaga kerja sesuai dengan fungsinya yaitu melakukan pengawasan norma ketenagakerjaan yang berkenaan dengan pengupahan.

Lebih lanjut beliau mengemukakan bahwa upaya lainnya yaitu dengan melaksanakan monitoring dan pengawasan secara rutin dengan cara terjun langsung ke setiap perusahaan dengan memeriksa berkas-berkas yang ada dan juga dengan melakukan wawancara baik dengan pemilik perusahaan ataupun dengan para buruh guna mengetahui keadaan yang sesungguhnya apakah sudah sesuai dengan dokumen wajib lapor perusahaan yang diserahkan kepada pegawai bagian pengawas Dinas Tenaga Kerja.

Menanggapi pendapat tersebut, penulis berpandangan bahwa memang pada dasarnya upah minimum buruh yang ada di PT. SDIC Papua Indonesia Cement Manokwari. Sudah sesuai aturan. Berdasarkan Surat Keputusan Gubernur Papua Barat Nomor 561/198/11/2017 Tentang Penetapan Upah Minuman Provinsi (UMP) dan Upah Minimum Sektor Provinsi Papua Barat Tahun 2018, maka setiap perusahaan harus menentukan upah sebesar Rp 2.667.000. adapun upah yang diberikan bagi pekerja pada PT. SDIC Papua Indonesia Cement Manokwari, adalah sama dengan jumlah upah minimum yakni Rp 2.667.000. 
Meskipun pada dasarnya upah minimum yang diberikan jumlahnya sama, namun dalam pelaksanaannya tidak demikian. Pada Tahun 2017250 pekerja PT SDIC Papua Cement Indonesia melakukan aksi mogok kerja. Para pekerja menuntut kejelasan upah yang dibayarkan pihak perusahaan, karena tidak sesuai dengan kontrak kerja dan aturan ketenagakerjaan. Koordinator aksi, Beny Tahirito, mengatakan ${ }^{12}$, sesuai surat keputusan (SK) Gubernur Papua Barat, apabila perusahaan membayar gaji di bawah upah minimum provinsi (UMP), maka perusahaan melanggar aturan. Diungkapkannya, di slip gaji yang diterima sebelumnya, tertera upah dan tunjangan, tetapi setelah berjalan beberapa bulan, upah dan tunjangan tidak tertera lagi di dalam slip gaji. Bahkan, terdapat pemotongan sebesar Rp. 200.000 yang tidak jelas tujuannya.

Menurut Yusab Minggo yang juga merupakan salah satu pekerja pada PT SDIC Papua Cement Indonesia kepada penulis pada tanggal 7 Maret 2018, mengemukakan bahwa:

Persoalan ini bukan baru terjadi, melainkan sudah berlarut-larut sampai 2 tahun, tetapi terus didiamkan semua pekerja. Beliau menambahkan bahwa para pekerja sudah sering menyampaikan aspirasi berulang kali, tetapi tidak pernah ditanggapi pihak perusahaan. Bahkan pihak perusahaan tidak memiliki itikad baik untuk menemui para pekerja untuk menyelesaikan persoalan ini. Lebih lanjut dikemukakan bahwa hal lain yang membingungkan para pekerja, nilai yang tertera di slip gaji tidak sama dengan upah yang diterima pekerja. Menurutnya, hal ini harus dijelaskan kepada pekerja agar jelas dan bisa dipahami.

Pada kesempatan yang berbeda, penulis melakukan wawancara dengan Pascalina Yamlean pada tanggal 13 Maret 2018, selaku Kepala Dinas Tenaga Kerja dan Transmigrasi Papua Barat, pada intinya beliau mengemukakan bahwa saat ini pihaknya sedang memfasilitasi penyelesaian masalah tersebut, kami berharap, persoalan ini selesai secara baik melalui pertemuan dia pihak (Bipartit) antara perusahaan dengan karyawan. Dalam persoalan ini karyawan menuntut perusahaan memberi kejelasan terkait gaji serta seluruh hak mereka sebagai pekerja. Laporan memang sudah masuk ke Dinas, Kami pun tentu harus bertindak sesuai prosedur sehingga pada tahap awalnya ini kami serahkan persoalan ini agar diselesaikan secara internal yakni secara bipartit. Kami berharap, persoalan ini selesai melalui pertemuan tersebut, sehingga tidak perlu ada proses Tripartite yang melibatkan Disnaker. Ditambahkan pula bahwa pengawasan ketenagakerjaan merupakan kewenangan Disnasker provinsi sedangkan pembinaan tugas

12 Pasific Pos, Op.Cit. 
kabupaten. Diharapkan perusahaan dan karyawan berkoordinasi dengan Disnakertrans Kabupaten Manokwari.

Dari pendapat di atas, dikemukakan bahwa Para pekerja meminta kejelasan dari perusahaan tentang hak-haknya, hal ini menunjukkan terdapat persoalan terkait dengan perjanjian kerja yang di sepakati. Bagaimana mungkin pekerja masih tidak memahami hak-haknya sementara mereka telah bekerja di Perusahaan. Disnakertrans puan terlihat saling lempar tangan. Pengawasan ketenagakerjaan menjadi kewenangan Dinasker provinsi, sedangkan pembinaan tugas Disnaker kabupaten. Kepala Dinas Tenaga Kerja dan Transmigrasi (Kadisnakertrans) Provinsi Papua Barat mengarahkan, perusahaan dan karyawan dapat berkoordinasi dengan Disnaker Kabupaten Manokwari. Hal ini mengindikasikan bahwa terdapat persoalan ketenagakerjaan yang sistematis, yakni tidak hanya pada tahap penyusunan perjanjian kerja saja, melainkan juga permasalahan pengawasan dan pembinaan perusahaan selaku pihak yang menggunakan jasa pekerja.

\section{KESIMPULAN}

Perjanjian kerja antara karyawan dengan PT. SDIC Papua Indonesia Cement Manokwari pada dasarnya merupakan kesepakatan pihak perusahaan dengan pihak serikat pekerja, namun demikian kedudukan yang tidak berimbang secara ekonomis, mengakibatkan kesepakatan berjalan satu arah dimana perusahaan lebih dominan dalam menentukan isi kontrak, sehingga asas kebebasan berkontrak kurang terpenuhi. Pelaksanaan perjanjian antara pekerja/karyawan dengan PT. SDIC Papua Indonesia Cement Manokwari dalam memperoleh hak-hak dasar Pengupahan kurang terimplementasi dengan baik. Hal ini dikarenakan terdapat pemotongan gaji karyawan yang tidak diketahui oleh karyawan. Hal ini telah disampaikan kepada pemerintah dalam hal ini Dinas Tenaga kerja dan transmigrasi dan saat ini sementara dalam proses penyelesaian dengan pihak perusahaan.

Pengawasan yang dilakukan pemerintah dalam hal ini dinas tenaga kerja dan transmigrasi, sebaiknya tidak hanya dilakukan pada saat pelaksanaan perjanjian kerja saja, melainkan juga pada saat penyusunan perjanjian kerja. Pihak pemerintah harus memosisikan diri sebagai pihak yang menyeimbangkan kedudukan para pihak dalam hal ini pekerja dan perusahaan. Dengan adanya keseimbangan para pihak, maka perjanjian yang dihasilkan juga akan berkeadilan bagi seluruh pihak. Selain itu, pekerja dan pihak perusahaan harus mengoptimalkan peran organisasi serikat pekerja, khususnya dalam hal pembuatan perjanjian. Perwakilan pekerja harus melakukan musyawarah sebelum 
perumusan perjanjian kerja dengan pihak perusahaan, dan juga melakukan sosialisasi isi kontrak setelah adanya kesepakatan dengan pihak perusahaan.

\section{Daftar Pustaka}

\section{Buku}

Agusmidah, Dinamika Hukum Ketenagakerjaan Indonesia, Medan: USU Press, 2010.

Asyhadie, Zaeni, Hukum Kerja, Jakarta: RajaGrafindo Persada, 2007.

Budiono, Herlien, Kumpulan Tulisan Hukum Perdata di Bidang Kenotariatan, Bandung: Citra Aditya Bakti, 2007.

Husni, Lalu, Hukum Ketenagakerjaan Indonesia, Jakarta: Raja Grafindo Persada, 2000.

Simamora, Yohanes Sogar, Hukum Perjanjian, Prinsip Hukum Kontrak Pengadaan Barang Dan Jasa Oleh Pemerintah. Yogyakarta: LaksBang Pressindo, 2009.

Sjahdeini, Sutan Remy, Kebebasan Berkontrak dan Perlindungan Yang Seimbang Bagi Para Pihak Dalam Perjanjian Kredit Bank di Indonesia. Jakarta: Institut Bankir Indonesia, 1993.

\section{Jurnal}

Aziz, Rizka Amelia, "Penerapan Perjanjian Kerja Waktu Tertentu (PKWT) Terhadap Pekerja Outsourcing Pasca Putusan MK No. 27/PUU-IX/2011" Jurnal Hukum Lex Jurnalica Vol.13 No.3, 2016.

Roy, Subir K. "Vulnerability of Elderly Women: Victim of Gender Discrimination". Hasanuddin Law Review, 3(1), 1-13, 2017, doi: http://dx.doi.org/10.20956/halrev.v3i1.560

\section{Internet}

Badan Pusat Statistik, "Rata-rata Gaji di Papua Kalahkan Jawa Barat", Katadata, http://databoks.katadata.co.id/datapublish/2017/01/27/10-provinsi-denganrata-rata-gaji-pekerja-terbesar, diakses pada tanggal 14 Oktober 2017, Pukul 09.00.

Pasific Pos, "250 Pekerja Lebih PT SDIC Cement Indonesia Mogok", Pasific Pos, https://www.pasificpos.com/item/16495-250-pekerja-lebih-pt-sdic-cementindonesia-mogok. Diakses taggal 13 Januari 2017. Pukul 14.00 WIT. 